\title{
Applications of Low-Emissivity Hybrid Insulation in South Korea
}

\author{
Young Cheol Kwon \\ Department of Architecture, Halla Universtiy, Wonju, South Korea \\ Email:yckwon@halla.ac.kr
}

Received 24 April 2016; accepted 16 July 2016; published 19 July 2016

\begin{abstract}
Low-Emissivity Hybrid Insulation has been developed in South Korea. It combines both resistive and reflective insulating principle. It is composed with many layers of reflective aluminum foils and honeycomb-structure air cells with polyethylene foam. This paper introduces recent South Korean building insulation code and the applications of Low-Emissivity Hybrid Insulation to meet the code.
\end{abstract}

\section{Keywords}

Low-Emissivity Hybrid Insulation, Building Energy Saving, Building Insulation Code, Insulation Application, Overall Thermal Transmittance

\section{Introduction}

Low-Emissivity Hybrid Insulation is a multilayer product consisting of layers of aluminum foil and a honeycomb structure produced from polyethylene foam. The resulting structure creates reflective airspaces within the cavity that reduce radiant heat transfer and heat flow by convection. The use of aluminum foil ensures a minimum 95\% reduction in radiation across the enclosed regions.

Low-Emissivity Hybrid Insulation has a foil surface emissivity of 0.04 with enclosed air cells between foils. Its core material is polyethylene foam with 35 times expansion, which is expanded to make air cells. The enclosed air cells with foil reduce convective and radiative heat transfer [1].

Figure 1 shows a 20 mm-thick Low-Emissivity Hybrid Insulation structure.

As Low-Emissivity Hybrid Insulation is not a homogeneous material, it is impossible to measure its thermal conductivity. Its insulating performance is measured by a Hot Box Test in accordance with ISO 8990 (Thermal Insulation-Determination of steady-state thermal transmission properties-Calibrated and guarded hot box).

It is necessary to verify the thermal resistance of its constitution materials to improve the insulating performance of Low-Emissivity Insulation.

This paper discusses the insulating characteristics of Low-Emissivity Hybrid Insulation depending on heat transfer paths and materials. Low-Emissivity Hybrid Insulation is composed of separated reflective air cells and polyethylene foam partitions between low-emissivity aluminum foils as shown in Figure 1. This means that Low-Emissivity Hybrid Insulation is divided into two parts according to the heat transfer paths such as reflective 


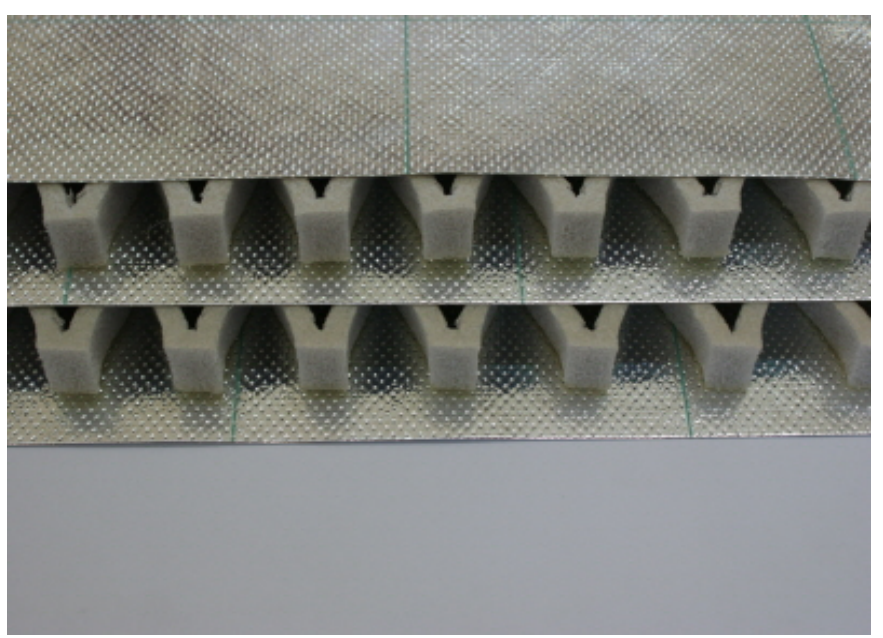

Figure 1. 20 mm-Thick low-emissivity hybrid insulation.

air cell and conductive polyethylene foam. Comprehensive thermal transmittance tests were conducted for the Low-Emissivity Hybrid Insulation of specimens of various thicknesses. The thicknesses of the specimens were $10,20,30,40,50,60,80$, and $100 \mathrm{~mm}$. Based on the test results, its insulation-affecting factors were in-vestigated using a trial-and-error method.

\section{Insulating Performance of Low-Emissivity Hybrid Insulation}

To verify the high efficiency of Low-Emissivity Hybrid Insulation, it was tested by an accredited laboratory designated by the South Korean government. Comprehensive thermal transmittance tests were conducted for the Low-Emissivity Hybrid Insulation of specimens of various thicknesses. The thicknesses of the specimens were $10,20,30,40,50,60,80$, and $100 \mathrm{~mm}$. The comprehensive thermal transmittance test was conducted in accordance with ISO 8990 (Thermal Insulation-Determination of Steady-State Thermal Transmission Properties-Calibrated and Guarded Hot Box). Figure 2 shows a drawing of the test specimen.

The test specimen size is $1500 \mathrm{~mm} \times 1500 \mathrm{~mm}$. Figure 3 shows the locations of the temperature sensors.

To get more accurate measurement results, three temperature sensors were located at each point. The temperature at each point was determined by averaging the three measured values.

The hot box facility was calibrated using a polystyrene foam board whose thermal conductivity had been acquired from a heat flow meter apparatus test at an accredited laboratory designated by KOLAS, the South Korea Laboratory Accreditation Scheme.

Tests were conducted with a hot region temperature of $20^{\circ} \mathrm{C}$ and a cold region temperature of $0^{\circ} \mathrm{C}$. The heat flow rate from the hot region to the cold region is determined from energy input to the hot region as in the case with ASTM C 1363. The overall thermal transmittance was calculated after steady-state conditions had been achieved. Data were recorded three times every hour and averaged. The overall thermal transmittance $(U)$ can be obtained from Equation (1) [2].

$$
U=1 / R=Q /((T h-T c) \times A)
$$

$U$ : Overall thermal transmittance $\left(\mathrm{W} / \mathrm{m}^{2} \cdot \mathrm{K}\right)$.

$R$ : Overall thermal resistance $\left(\mathrm{m}^{2} \cdot \mathrm{K} / \mathrm{W}\right)$.

Q: Supplied heat (W).

Th: Temperature of hot region $\left({ }^{\circ} \mathrm{C}\right)$.

Tc: Temperature of cold region $\left({ }^{\circ} \mathrm{C}\right)$.

A: Area of specimen $\left(\mathrm{m}^{2}\right)$.

Test results are shown in Table 1.

Table 1 shows that a $100 \mathrm{~mm}$ thick Low-Emissivity Hybrid Insulation can meet the overall thermal transmittance of walls and roofs of Passive Houses which is below $0.15 \mathrm{~W} / \mathrm{m}^{2} \cdot \mathrm{K}$ [5].

Figure 4 shows the required thickness of various insulations to meet the overall thermal transmittance of 

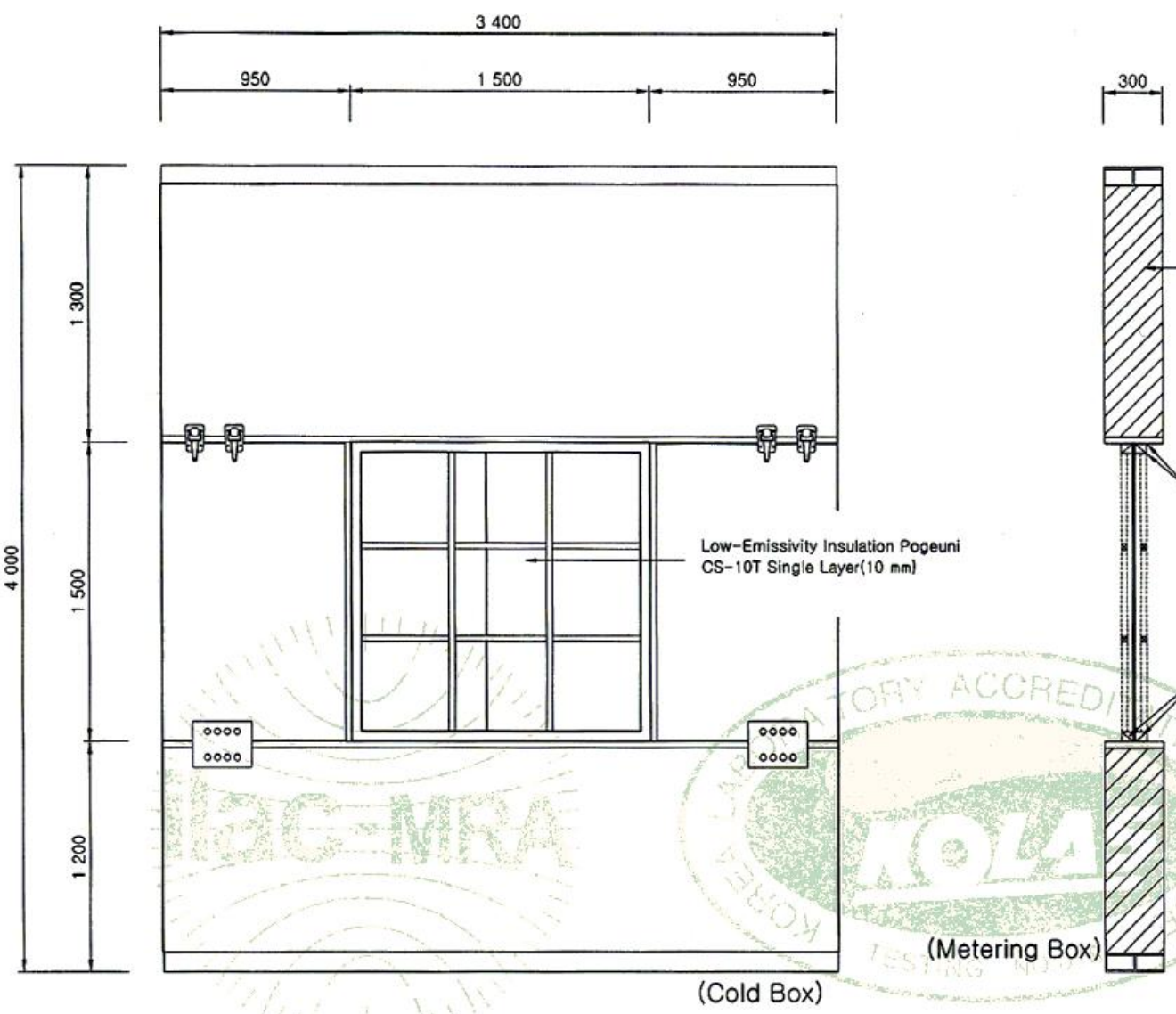

(Metering Box)

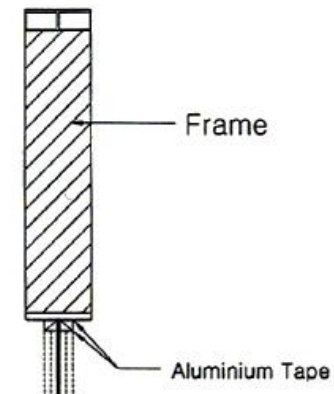

Elevation

\section{Vertical Section}

Figure 2. Drawing of the test specimen.

Passive Houses of $0.15 \mathrm{~W} / \mathrm{m}^{2} \cdot \mathrm{K}$.

While as thick as $240 \mathrm{~mm}$ of EPS, whose thermal conductivity is $0.036 \mathrm{~W} / \mathrm{mK}$, should be used, as thick as 30 $\mathrm{mm}$ of Enervac, which is a kind of a vacuum insulation panel, can be used as insulation for Passive Houses [6]. From Table 1 and Figure 4, we can assume that Low-Emissivity Hybrid Insulation has the same insulating performance as Aerogel.

\section{Low-Emissivity Hybrid Insulation Thickness to Meet the Required U-Values by South Korean Building Insulation Code}

Table 2 shows required U-values for central region by South Korean building insulation codes [7].

Table 2 indicates that required U-value for exterior wall adjacent to outside directly should be less than 0.36 $\mathrm{W} / \mathrm{m}^{2} \cdot \mathrm{K}$. For the designer's convenience, the building insulation codes provide the required insulation thickness according to each insulation grade. Table $\mathbf{3}$ shows the required thickness of insulation to obtain the required U-values.

The insulation grade is given as A, B, C, D according to thermal conductivity of insulation.

Table 4 shows how the grade is determined.

Table 4 indicates, for example, that XPS, Neopor, PU and high-density Glass Wool belong to Grade “A”.

According to Table 3 and Table 4, Existing insulations should be used as thick as $85 \mathrm{~mm}$ or $100 \mathrm{~mm}$ for an exterior wall which is adjacent to outside directly for central region in South Korea.

On the bases of the test results in Table 2, $30 \mathrm{~mm}$ or $40 \mathrm{~mm}$ Low-Emissivity Hybrid Insulation can meet the required $U$ value for the same wall. This means that the thickness of Low-Emissivity Hybrid Insulation required to meet building codes is less than that of many competing insulations. 


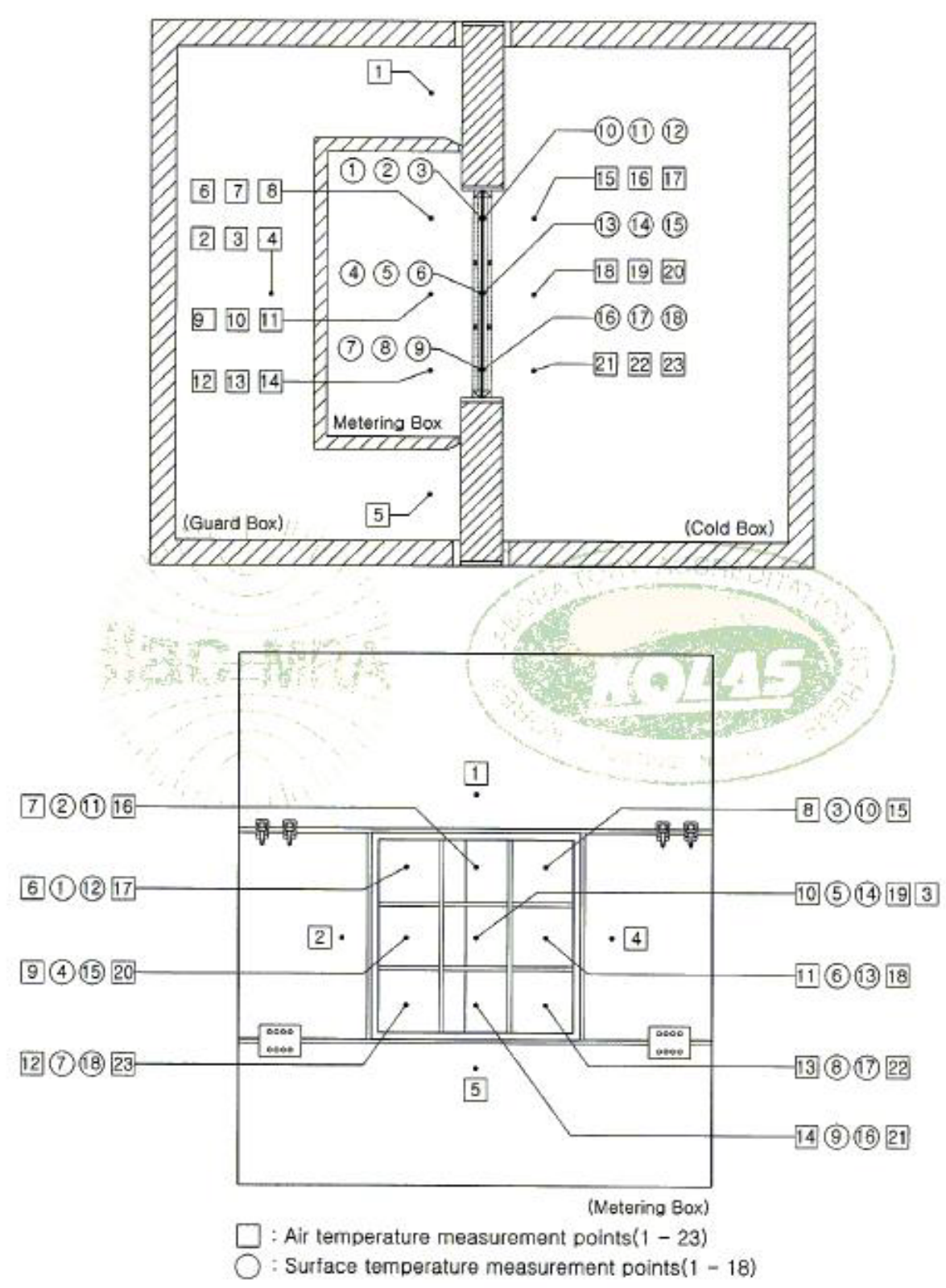

Figure 3. Location of the temperature sensors.

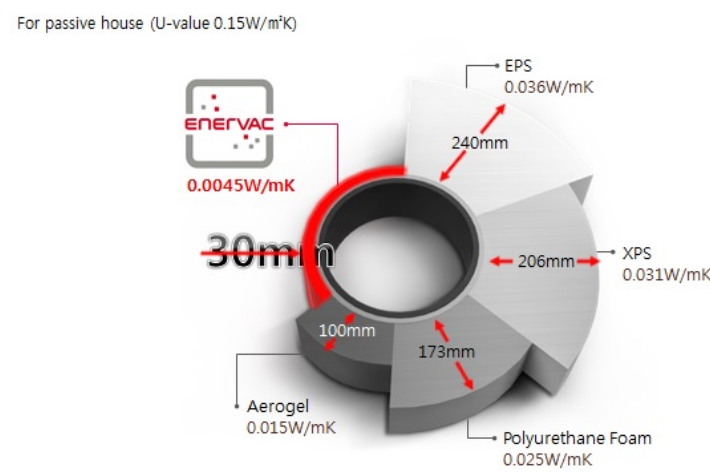

Figure 4. Required thickness of various insulations for passive houses. 
Table 1. Overall thermal transmittance and thermal resistance of low-emissivity hybrid insulation [3] [4].

\begin{tabular}{cccc}
\hline \multirow{2}{*}{$\begin{array}{c}\text { Thickness } \\
(\mathrm{mm})\end{array}$} & $\begin{array}{c}\text { Overall thermal } \\
\text { transmittance } \\
\left(\mathrm{W} / \mathrm{m}^{2} \cdot \mathrm{K}\right)\end{array}$ & \multicolumn{2}{c}{ Thermal resistance } \\
\cline { 3 - 4 }$(0$ & 1.12 & 0.89 & 5.10 \\
20 & 0.55 & 1.82 & 10.3 \\
30 & 0.45 & 2.22 & 12.6 \\
40 & 0.32 & 3.13 & 17.8 \\
50 & 0.27 & 3.70 & 21.0 \\
60 & 0.22 & 4.55 & 25.8 \\
80 & 0.19 & 5.26 & 29.9 \\
100 & 0.14 & 7.14 & 40.5 \\
\hline
\end{tabular}

Table 2. Required u-values for the central region of South Korea.

\begin{tabular}{|c|c|c|c|}
\hline \multicolumn{3}{|c|}{ Building envelope } & Required U-value $\left(\mathrm{W} / \mathrm{m}^{2} \cdot \mathrm{K}\right)$ \\
\hline \multirow{2}{*}{ Exterior wall } & \multicolumn{2}{|c|}{ Adjacent to outside directly } & Less than 0.36 \\
\hline & \multicolumn{2}{|c|}{ Adjacent to outside indirectly } & Less than 0.49 \\
\hline \multirow{2}{*}{ Roof } & \multicolumn{2}{|c|}{ Adjacent to outside directly } & Less than 0.20 \\
\hline & \multicolumn{2}{|c|}{ Adjacent to outside indirectly } & Less than 0.29 \\
\hline \multirow{4}{*}{$\begin{array}{c}\text { Floor } \\
\text { of the lowest } \\
\text { floor }\end{array}$} & \multirow{2}{*}{ Adjacent to outside directly } & Floor heating & Less than 0.30 \\
\hline & & No floor heating & Less than 0.41 \\
\hline & \multirow{2}{*}{ Adjacent to outside indirectly } & Floor heating & Less than 0.43 \\
\hline & & No floor heating & Less than 0.58 \\
\hline \multicolumn{3}{|c|}{ Sidewall of apartment building } & Less than 0.27 \\
\hline \multirow{2}{*}{$\begin{array}{c}\text { Floor } \\
\text { between levels }\end{array}$} & \multicolumn{2}{|c|}{ Floor heating } & Less than 0.81 \\
\hline & \multicolumn{2}{|c|}{ No floor heating } & Less than 1.16 \\
\hline \multirow{4}{*}{$\begin{array}{l}\text { Fenetrations } \\
\text { and doors }\end{array}$} & \multirow{2}{*}{ Adjacent to outside directly } & Apartment & Less than 2.10 \\
\hline & & Others & Less than 2.40 \\
\hline & \multirow{2}{*}{ Adjacent to outside indirectly } & Apartment & Less than 2.80 \\
\hline & & Others & Less than 3.20 \\
\hline
\end{tabular}

Table 3. Required thickness of insulation for central region.

\begin{tabular}{|c|c|c|c|c|c|c|}
\hline & & \multirow{2}{*}{$\begin{array}{l}\text { Required insulation thickness } \\
\text { according to Grade }\end{array}$} & \multicolumn{4}{|c|}{ Thickness (mm) } \\
\hline \multicolumn{2}{|c|}{ Building envelope } & & A & B & $\mathrm{C}$ & $\mathrm{D}$ \\
\hline \multicolumn{3}{|c|}{ Adjacent to outside directly } & 85 & 100 & 115 & 130 \\
\hline LXteTIUI WaII & \multicolumn{2}{|c|}{ Adjacent to outside indirectly } & 60 & 70 & 80 & 90 \\
\hline \multirow{4}{*}{$\begin{array}{c}\text { Floor } \\
\text { of the lowest floor }\end{array}$} & \multirow{2}{*}{$\begin{array}{l}\text { Adjacent to outside } \\
\text { directly }\end{array}$} & Floor heating & 105 & 125 & 140 & 160 \\
\hline & & No floor heating & 75 & 90 & 100 & 115 \\
\hline & \multirow{2}{*}{$\begin{array}{l}\text { Adjacent to outside } \\
\text { indirectly }\end{array}$} & Floor heating & 70 & 80 & 90 & 105 \\
\hline & & No floor heating & 50 & 55 & 65 & 70 \\
\hline \multirow{3}{*}{ Roof } & \multicolumn{2}{|c|}{ Adjacent to outside directly } & 160 & 190 & 215 & 245 \\
\hline & \multicolumn{2}{|c|}{ Adjacent to outside indirectly } & 105 & 125 & 145 & 160 \\
\hline & \multicolumn{2}{|c|}{ Sidewall of apartment building } & 120 & 140 & 160 & 175 \\
\hline \multirow{2}{*}{$\begin{array}{c}\text { Floor } \\
\text { between levels }\end{array}$} & \multicolumn{2}{|r|}{ Floor heating } & 30 & 35 & 45 & 50 \\
\hline & \multicolumn{2}{|r|}{ Other } & 20 & 25 & 25 & 30 \\
\hline
\end{tabular}




\section{Applications of Low-Emissivity Hybrid Insulation in South Korea}

Low-Emissivity Hybrid Insulation is getting to be used more and more buildings such as schools, government offices, residential buildings and commercial buildings in South Korea. It is usually applied on the reinforced concrete walls and roofs as thick as $60-80 \mathrm{~mm}$. It is unusually used as main insulation for a building in South Korea. Recently, Low-Emissivity Insulation with fire-retarding property has been developed and used as exterior insulation for large buildings above 6 stories.

Figure 5 shows various building applications of Low-Emissivity Hybrid Insulation in South Korea.

Table 4. Insulation classification according to thermal conductivity in South Korea.

\begin{tabular}{|c|c|c|c|}
\hline \multirow{2}{*}{ Grade } & \multicolumn{2}{|c|}{ Thermal conductivity } & \multirow{2}{*}{$\begin{array}{c}\text { Insulation type } \\
\text { Note }\end{array}$} \\
\hline & $\mathbf{W} / \mathbf{m K}$ & $\mathrm{kcal} / \mathrm{mh} \cdot{ }^{\circ} \mathrm{C}$ & \\
\hline A & 0.034 or lower & 0.029 or lower & $\begin{array}{l}\text {-XPS (Extruded Polystyrene Board) outstanding type, type 1, type 2, type } 3 \\
\text {-EPS (Expanded Poly Styrene) class } 2 \text { (Neopor) No. } 1 \text {, No. 2, No. 3, No. } 4 \\
\text {-Rigid polyurethane foam Class } 1 \mathrm{No} .1 \text {, No. } 2 \text {, No. } 3 \text { and Class } 2 \text { No. } 1 \text {, No. 2, No. } 3 \\
\text {-Glass Wool insulating board } 48 \mathrm{~K}, 64 \mathrm{~K}, 80 \mathrm{~K}, 96 \mathrm{~K}, 120 \mathrm{~K} \\
\text {-Thermal Conductivity is } 0.034 \mathrm{~W} / \mathrm{mK}\left(0.029 \mathrm{kcal} / \mathrm{mh} \cdot{ }^{\circ} \mathrm{C}\right) \text { or lower as other } \\
\text { insulations. }\end{array}$ \\
\hline B & $0.035-0.040$ & $0.030-0.034$ & $\begin{array}{l}\text {-EPS (Expanded Poly Styrene) class } 1 \text { No. } 1 \text {, No. } 2 \text {, No. } 3 \\
\text {-Mineral Wool No. } 1 \text {, No. } 2 \text {, No. } 3 \\
\text {-Glass Wool } 24 \mathrm{~K}, 32 \mathrm{~K}, 40 \mathrm{~K} \\
\text {-Thermal Conductivity is } 0.035-0.040 \mathrm{~W} / \mathrm{mK}\left(0.030-0.034 \mathrm{kcal} / \mathrm{mh} \cdot{ }^{\circ} \mathrm{C}\right) \text { as other } \\
\text { insulations. }\end{array}$ \\
\hline $\mathrm{C}$ & $0.041-0.046$ & $0.035-0.039$ & $\begin{array}{l}\text {-EPS(Expandable Poly Styrene) class } 1 \mathrm{No} .4 \\
\text {-Thermal Conductivity is } 0.041-0.046 \mathrm{~W} / \mathrm{mK}\left(0.035-0.039 \mathrm{kcal} / \mathrm{mh} \cdot{ }^{\circ} \mathrm{C}\right) \text { as other } \\
\text { insulations. }\end{array}$ \\
\hline $\mathrm{D}$ & $0.047-0.051$ & $0.040-0.044$ & $\begin{array}{l}\text {-Thermal Conductivity is } 0.047-0.051 \mathrm{~W} / \mathrm{mK}\left(0.040-0.044 \mathrm{kcal} / \mathrm{mh} \cdot{ }^{\circ} \mathrm{C}\right) \text { as other } \\
\text { insulations. }\end{array}$ \\
\hline
\end{tabular}

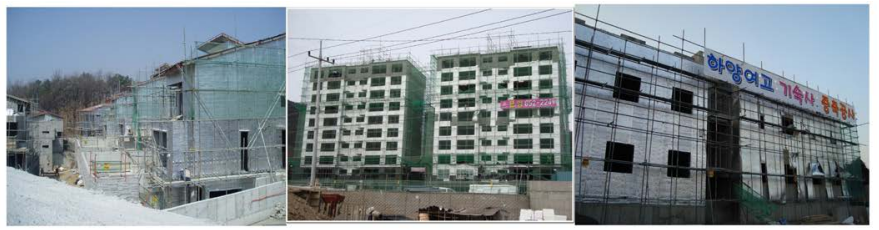

Residential Buildings

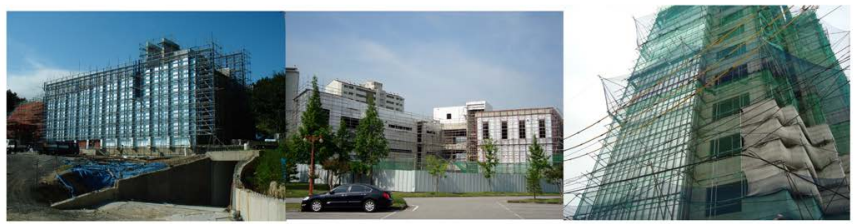

Commercial Buildings

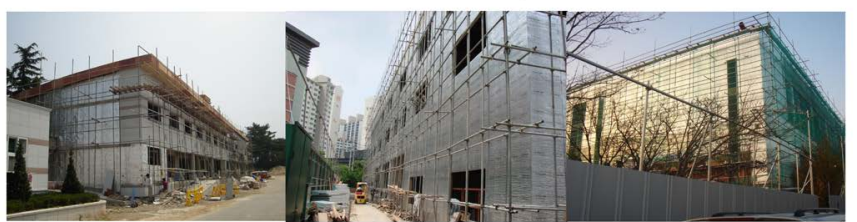

Public Buildings

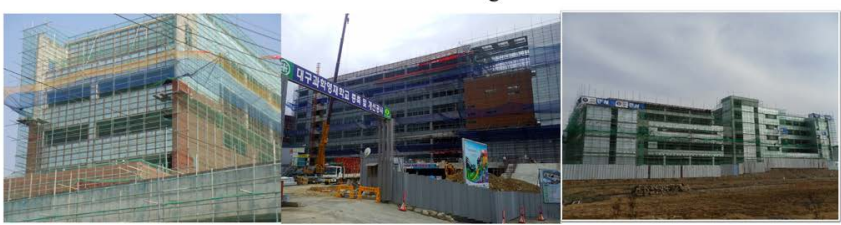

Schools

Figure 5. Various building applications of low-emissivity hybrid insulation in Korea. 


\section{Acknowledgements}

This work was supported by the National Research Foundation of South Korea (NRF) and the grant funded by the South Korea government (MEST) (No. 2014R1A1A4A01005565).

\section{References}

[1] Kwon, Y.C., Kim, Y.O. and Lee, G.Y. (2014) An Innovative Low-Emissivity Insulation Developed in South Korea. ASTM STP, 1574, 101-118. http://dx.doi.org/10.1520/stp157420130082

[2] Kwon, Y.C. and Kim, Y.O. (2010) A Study on the Development of a High-Efficiency Low-Emissivity Insulation. Journal of KIAEBS, 4, 89-95.

[3] http://passipedia.passiv.de/ppediaen/planning/thermal_protection/external_walls/passive_house_suitable_wall_systems

[4] Kwon, Y.C. (2012) Insulation Applications for Buildings in South Korea. Proceedings of 7th Global Insulation Conference, Latvia.

[5] Rhee, E.K., et al. (2006) Architectural Environmental Planning. Taelim Publishing Co., 2013 ASHRAE HandbookFundamentals (SI), 26.20.

[6] Kwon, Y.C. and Kim, K.M. (2015) A Study on the Insulating Characteristics of Low-E Insulation Depending on Heat Transfer Paths and Materials. Workshop on Architecture, South Korea. http://dx.doi.org/10.14257/astl.2015.89.15

[7] Kwon, Y.C. and Kim, K.M. (2016) Insulation-Affecting Factors of Low-Emissivity Insulation. International Journal of Applied Engineering Research, 11, 838-842.

\section{Submit or recommend next manuscript to SCIRP and we will provide best service for you:}

Accepting pre-submission inquiries through Email, Facebook, LinkedIn, Twitter, etc. A wide selection of journals (inclusive of 9 subjects, more than 200 journals)

Providing 24-hour high-quality service

User-friendly online submission system

Fair and swift peer-review system

Efficient typesetting and proofreading procedure

Display of the result of downloads and visits, as well as the number of cited articles

Maximum dissemination of your research work

Submit your manuscript at: http://papersubmission.scirp.org/ 